Pak. j. sci. ind. res. Ser. B: biol. sci. 201558 (3) 155-158

\title{
Physicochemical and Amino Acid Profiling of Cheddar, Mozzarella and Paneer Whey
}

\author{
Sheraz Ahmed ${ }^{a *}$, Mian Kamran Sharif ${ }^{a}$, Masood Sadiq Butt ${ }^{\mathrm{a}}$ and Haq Nawaz ${ }^{\mathrm{b}}$ \\ ${ }^{a}$ Faculty of Food, Nutrition and Home Sciences, University of Agriculture, Faisalabad-38040, Pakistan \\ ${ }^{b}$ Institute of Animal Nutrition and Feed Technology, University of Agriculture, Faisalabad-38040, Pakistan
}

(received March 13, 2015; revised June 15, 2015; accepted June 28, 2015)

\begin{abstract}
The present study characterised locally available whey samples of cheddar, mozzarella and paneer for physicochemical and nutritional attributes. The results revealed that the cheddar whey exhibited $\mathrm{pH}(5.41 \pm 0.16)$, crude protein $(0.83 \pm 0.03 \%)$, fat $(0.25 \pm 0.01 \%)$, lactose $(4.95 \pm 0.21 \%)$ and total solids $(6.55 \pm 0.27 \%)$, slightly higher than those of mozzarella and paneer whey. On the other hand, the paneer whey showed acidity $(0.30 \pm 0.01)$ and ash content $(0.56 \pm 0.02)$, slightly higher than those of cheddar and mozzarella whey. Furthermore, the mozzarella whey revealed the total plate count values $(3.17 \pm 0.09 \times$ $10^{4} \mathrm{cfu} / \mathrm{mL}$ ), slightly higher than those of cheddar and paneer whey samples. The paneer whey contained the amount of calcium $(25.02 \pm 1.34)$, magnesium $(4.88 \pm 0.23)$, sodium $(32.11 \pm 1.37)$ and potassium $(97.55 \pm 3.54)$ slightly higher, when compared to those of cheddar and mozzarella whey. The cheddar whey possessed the highest amount of essential and non-essential amino acid contents, followed by mozzarella and paneer whey. Thus, cheddar whey exhibited the best physicochemical and nutritional profile among all the whey samples, so it can be used to prepare high quality novel and nutritious sports drink for sportsman.
\end{abstract}

Keywords: whey proteins, nutrition, cheese-whey, by-products, mozzarella whey

\section{Introduction}

The food industry is producing massive quantities of by- and co-products being discharged in streams or dumped into soil resulting in environmental pollution. These by-products are exploitable source of bioactive components. The technologically advanced countries are extracting valuable ingredients from these wastes including proteins, peptides, organic acids, vitamins, minerals, lactose etc. Whey is nutritious co-product of cheese manufacturing industry with great potential for diverse food applications due to its high quality proteins and essential amino acids. Depending upon the raw material (enzyme or acid) used in milk coagulation; it is broadly classified into sweet whey or acid whey (Zimecki and Kruzel, 2007; Gill et al., 2000; Singh et al., 1999). The current world production of whey is about 125 million tonnes, about $64 \%$ is produced in European countries and $24 \%$ in North America. Pakistan contributes almost 45000 tonnes whey per year. The channa (gram) and paneer (cheese) whey give the major contribution (80\%) in total whey production (Naik et al., 2009). Playne (2003) reported that $55 \%$ of total whey is treated and converted into various valuable food ingredients.

*Author for correspondence; E-mail: sheraz1080@yahoo.com
Jaun et al. (2009) revealed lactose 5\%, soluble proteins 0.6 to $0.8 \%$, lipids $0.5 \%$ and minerals 8 to $10 \%$. Whey salts contain more than $50 \%$ of potassium chloride and sodium chloride and salts of calcium (phosphates). Whey proteins are approximately $20 \%$ of the milk proteins and comprised of $\beta$-lactoglobulin $(50 \%), \alpha$ lactalbumin $(20 \%)$, bovine serum albumin $(10 \%)$ and other minor proteins (10\%) like lactoferrin, peptone, immunoglobins, prolactin, proteose, folate, calmodulin and binding proteins.

Otte et al. (2007) reported several applications of whey proteins in beverage, confectionary, desserts manufacturing, dairy and bakery industries because of certain functional and nutritional properties, such as solubility, whip ability, emulsification, viscosity, gelation, foam formation, firmness, creaminess to end product and heat stability.

Omole et al. (2012) considered whey protein as a useful ingredient for infant formula because of its low allergen causing ability, weight gain, as well as in protein fortified fruit juices and other healthy foods and drinks. The vitamins and minerals present in whey have high bioavailability, while its amino acid profile has high amount of branchedchain amino acids such as valine, isoleucine and leucine. 
The objective of the present study was to characterise the functional quality and nutritional attributes of cheddar, mozzarella and paneer whey, in order to assess its suitability to prepare sports drink for athlete.

\section{Materials and Methods}

Procurement of raw materials. Cheddar and mozzarella cheese whey were procured from Noon Dairies Bhalwal, Sargodha (Pakistan) and paneer whey was procured from Gourmet Foods, Lahore (Pakistan).All reagents (analytical and HPLC grade) \& standards were purchased from the Merck (Merck KGaA, Darmstadt, Germany) and SigmaAldrich (Sigma-Aldrich Tokyo, Japan).

Characterisation of whey. Cheddar, mozzarella and paneer whey samples were analysed for various physicochemical parameters including $\mathrm{pH}$, acidity, total solids, fat, crude protein, ash, lactose, mineral analysis and amino acid profile. Whey samples were also evaluated for microbial assay i.e. total plate count (TPC). The brief description of each is given:

pH. Electronic digital pH meter (EUTECH pH 510, Cyberscan, Singapore) was used.

Acidity. Whey samples were analysed for acidity through the titrimetric method following the procedure described in AOAC Method No. 947.05 (AOAC, 2006).

Fat. Fat content was calculated by Gerber method following the protocol of Djuric et al. (2004).

Crude protein. Crude protein was determined by Kjeldahl method using Kjeltech apparatus (Technik Gmbh, Behr Labor, Germany) following the procedure elaborated in AOAC Method No. 991.20 (AOAC 2006).

Ash content. Ash in whey was estimated by following the protocol given in AOAC Method No. 945.46 AOAC (2006).

Lactose. The lactose was determined through enzymatic method as explained in AOAC (2006).

Total solids. Total solids assessed according to AOAC Method No. 925.23 (AOAC, 2006).

Mineral profile. Whey was analysed for mineral assay (calcium, magnesium, sodium and potassium) following the procedure described in AOAC (2006).

Amino acid profile. Amino acid profile of whey samples was determined following the procedure of Walsh and Brown (2000).
Total plate count. Total plate count was determined by the procedure of Yousaf and Calstrom (2003).

Statistical analysis: The resulting data were subjected to statistical analysis using completely randomised design (Steel et al., 1997).

\section{Results and Discussion}

The results along with comprehensive debate are given below:

Characterisation of whey. Cheddar whey (sweet whey), mozzarella and paneer whey (acid whey) samples were evaluated for physicochemical and microbiological analysis including $\mathrm{pH}$, acidity, fat, crude protein, ash, lactose, total solids, minerals ( $\mathrm{Na}, \mathrm{K}, \mathrm{Ca}$ and $\mathrm{Mg}$ ) and total plate count (TPC). Furthermore, these whey samples were also analysed for amino acid profiling.

Physicochemical analysis. The sweet and acid liquid whey samples were assessed for various quality attributes. The results revealed high $\mathrm{pH}(5.41 \pm 0.16)$, crude protein $(0.83 \pm 0.03 \%)$, fat content $(0.25 \pm 0.01 \%)$, lactose concentration $(4.95 \pm 0.21 \%)$ and total solids $(6.55 \pm 0.27$ $\%)$ in cheddar whey whereas, acidity $(0.30 \pm 0.01)$ and ash content $(0.56 \pm 0.02)$ were observed in paneer whey. Total plate count (TPC) was slightly high $(3.17 \pm 0.09 \times$ $10^{4} \mathrm{cfu} / \mathrm{mL}$ ) in mozzarella whey (Table 1). The results of this instant activity are supported by various researchers with slight variations. The sweet whey contains higher values of $\mathrm{pH}(6.21 \pm 0.08)$, fat $(0.20 \pm 0.06 \%)$, protein $(0.53 \pm 0.28 \%)$, lactose $(5.0 \pm 0.05 \%)$ and total solids $(6.30 \pm 0.12 \%)$ while low $\mathrm{pH}(5.50 \pm 0.08)$, fat $(0.01 \pm$ $0 \%)$, protein $(0.41 \pm 0.07 \%)$, lactose $(4.50 \pm 0.89 \%)$ and total solids $(5.80 \pm 0.13 \%)$ were observed in acid whey (Goyal and Gandhi, 2009).

In a similar type of studies, it was observed that acid whey has $\mathrm{pH}(4.02-4.82)$, acidity $(0.34-0.40 \%)$, lactose (4.86-4.93\%), protein (0.41-0.42\%) total solids (6.40-6.50\%) and total plate count $\left(1.5 \times 10^{4}-2.60 \times 10^{4} \mathrm{cfu} / \mathrm{mL}\right)($ Singh et al., 2014; Shukla et al., 2013; Ismail et al., 2011). In a study, analysis of sweet liquid whey exhibited $0.46 \%$ protein, $0.20 \%$ fat, $5.74 \% \mathrm{SNF}, 6.14 \%$ total solids, 22.55 $\mathrm{mg} / 100 \mathrm{~g} \mathrm{Ca}, 32.08 \mathrm{mg} / 100 \mathrm{~g} \mathrm{Na}, 97 \mathrm{mg} / 100 \mathrm{~g} \mathrm{~K}$ and 4.72 $\mathrm{mg} / 100 \mathrm{~g} \mathrm{Mg}$ (Sakhale et al., 2012). The results of the present investigation are in harmony with the findings of Smithers (2008) who reported $0.1 \%$ fat, $0.7 \%$ protein, $4.9 \%$ lactose and $6.3 \%$ total solids in cheddar whey. Likewise, Djuric et al. (2004) reported pH 3.63, protein $0.45 \%$, fat $0.82 \%$, lactose $4.69 \%$, ash $0.50 \%$ and total solids $7 \%$ in cheddar whey. 
Table 1. Physicochemical and microbial analysis of cheddar, mozzarella and paneer whey

\begin{tabular}{llll}
\hline \hline Components & $\begin{array}{l}\text { Cheddar } \\
\text { whey }\end{array}$ & $\begin{array}{l}\text { Mozzarella } \\
\text { whey }\end{array}$ & $\begin{array}{l}\text { Paneer } \\
\text { whey }\end{array}$ \\
\hline pH & $5.41 \pm 0.16$ & $5.33 \pm 0.13$ & $5.09 \pm 0.12$ \\
Acidity (\%) & $0.26 \pm 0.01$ & $0.28 \pm 0.01$ & $0.30 \pm 0.01$ \\
Fat (\%) & $0.25 \pm 0.01$ & $0.24 \pm 0.01$ & $0.22 \pm 0.01$ \\
Crude protein (\%) & $0.83 \pm 0.03$ & $0.81 \pm 0.02$ & $0.78 \pm 0.02$ \\
Ash (\%) & $0.52 \pm 0.01$ & $0.53 \pm 0.01$ & $0.56 \pm 0.02$ \\
Lactose (\%) & $4.95 \pm 0.21$ & $4.93 \pm 0.20$ & $4.89 \pm 0.19$ \\
Total solids (\%) & $6.55 \pm 0.27$ & $6.51 \pm 0.24$ & $6.45 \pm 0.22$ \\
Total plate count & & & \\
$\left(10^{4}\right.$ cfu/mL) & $3.11 \pm 0.08$ & $3.17 \pm 0.09$ & $3.02 \pm 0.05$ \\
\hline
\end{tabular}

Values are expressed as means \pm standard deviation

Minerals profile of whey. Cheddar, mozzarella and paneer whey contain an appropriate level of minerals (Table 2). Goyal and Gandhi (2009) evaluated cheddar and paneer whey for mineral contents. It was found that cheddar whey contain calcium $(30 \mathrm{mg} / 100 \mathrm{~g})$, potassium (130 mg/100g), magnesium (3.6 mg/100g) and sodium (26 mg/100g) whereas, paneer whey contain slightly higher calcium (48 mg/100g), magnesium (5.9 mg/100g) and sodium $(35 \mathrm{mg} / 100 \mathrm{~g})$.

Amino acid profile of whey. Whey proteins contain both essential and non-essential amino acids in higher concentration as compared to vegetable proteins. Amino acid composition of whey samples revealed leucine as major essential amino acid in cheddar $(86.14 \pm 2.14 \mathrm{mg} / \mathrm{g})$, mozzarella $(85.88 \pm 2.11 \mathrm{mg} / \mathrm{g})$ and paneer whey $(82.09$ $\pm 2.16 \mathrm{mg} / \mathrm{g}$ ) followed by lysine with mean values 80.41 $\pm 2.34 \mathrm{mg} / \mathrm{g}, 79.97 \pm 2.21 \mathrm{mg} / \mathrm{g}$ and $77.54 \pm 2.01 \mathrm{mg} / \mathrm{g}$, respectively (Table 3 ). The concentrations of other essential amino acids including threonine, isoleucine, valine, methionine, phenylalanine, tryptophan and histidine, in sweet whey were $50.12 \pm 1.87,41.31 \pm 1.16,40.39 \pm 1.19$,

Table 2. Mineral profile of cheddar, mozzarella and paneer whey

\begin{tabular}{llll}
\hline \hline Minerals & $\begin{array}{l}\text { Cheddar } \\
\text { whey }\end{array}$ & $\begin{array}{l}\text { Mozzarella } \\
\text { whey }\end{array}$ & $\begin{array}{l}\text { Paneer } \\
\text { whey }\end{array}$ \\
\hline $\begin{array}{l}\text { Potassium } \\
(\mathrm{mg} / 100 \mathrm{~g})\end{array}$ & $94.23 \pm 2.34$ & $95.56 \pm 2.67$ & $97.55 \pm 3.54$ \\
$\begin{array}{l}\text { Sodium } \\
(\mathrm{mg} / 100 \mathrm{~g})\end{array}$ & $29.76 \pm 1.17$ & $30.32 \pm 1.23$ & $32.11 \pm 1.37$ \\
$\begin{array}{l}\text { Calcium } \\
(\mathrm{mg} / 100 \mathrm{~g})\end{array}$ & $23.76 \pm 1.09$ & $23.65 \pm 1.18$ & $25.02 \pm 1.34$ \\
$\begin{array}{l}\text { Magnesium } \\
(\mathrm{mg} / 100 \mathrm{~g})\end{array}$ & $4.34 \pm 0.12$ & $4.23 \pm 0.14$ & $4.88 \pm 0.23$ \\
\hline \hline
\end{tabular}

Values are expressed as means \pm standard deviation
$23.13 \pm 1.54,24.56 \pm 1.14,18.50 \pm 0.99,17.61 \pm 1.01$, while in acid whey as $48.34 \pm 1.97,40.05 \pm 1.86,37.76$ $\pm 2.02,22.16 \pm 1.24,21.45 \pm 1.05,17.24 \pm 1.15$ and 16.08 $\pm 1.03 \mathrm{mg} / \mathrm{g}$, respectively.

The means for non-essential amino acid contents indicated that glutamic acid was present in highest concentration in cheddar $(144.51 \pm 3.41 \mathrm{mg} / \mathrm{g})$, mozzarella (141.56 \pm 2.98 $\mathrm{mg} / \mathrm{g})$ and paneer whey $(137.67 \pm 3.22 \mathrm{mg} / \mathrm{g})$ followed by aspartic acid $(101.30 \pm 3.14 \mathrm{mg} / \mathrm{g} ; 99.34 \pm 3.17 ; 98.27 \pm$ $2.99 \mathrm{mg} / \mathrm{g}$ ) (Table 4). Likewise, concentrations of proline, serine, alanine, arginine, tyrosine, glycine and cysteine, in sweet whey was $62.08 \pm 3.01,44.16 \pm 2.12,50.23 \pm 2.01$, $21.47 \pm 1.94,30.07 \pm 2.13,12.09 \pm 0.98$ and $15.05 \pm 0.89$, where as in acid whey as $60.34 \pm 3.11,42.56 \pm 2.02,49.31$ $\pm 1.86,19.17 \pm 1.93,28.08 \pm 2.13,10.21 \pm 0.89$ and 13.87 $\pm 0.88 \mathrm{mg} / \mathrm{g}$ protein, respectively.

Whey protein isolate contain isoleucine $(61 \mathrm{mg} / \mathrm{g})$, leucine (122 mg/g), lysine (102 mg/g), methionine (33 $\mathrm{mg} / \mathrm{g})$, phenylalanine $(30 \mathrm{mg} / \mathrm{g})$, threonine $(68 \mathrm{mg} / \mathrm{g})$, tryptophan $(18 \mathrm{mg} / \mathrm{g})$ and valine $(59 \mathrm{mg} / \mathrm{g})$ as essential

Table 3. Essential amino acids in cheddar, mozzarella and paneer whey $(\mathrm{mg} / \mathrm{g}$ protein)

\begin{tabular}{llll}
\hline \hline $\begin{array}{l}\text { Essential } \\
\text { amino acids }\end{array}$ & $\begin{array}{l}\text { Cheddar } \\
\text { whey }\end{array}$ & $\begin{array}{l}\text { Mozzarella } \\
\text { whey }\end{array}$ & $\begin{array}{l}\text { Paneer } \\
\text { whey }\end{array}$ \\
\hline Leucine & $86.14 \pm 2.14$ & $85.88 \pm 2.11$ & $82.09 \pm 2.16$ \\
Lysine & $80.41 \pm 2.34$ & $79.97 \pm 2.21$ & $77.54 \pm 2.01$ \\
Threonine & $50.12 \pm 1.87$ & $50.04 \pm 2.15$ & $48.34 \pm 1.97$ \\
Isoleucine & $41.31 \pm 1.16$ & $41.13 \pm 2.01$ & $40.05 \pm 1.86$ \\
Valine & $40.39 \pm 1.19$ & $40.23 \pm 1.99$ & $37.76 \pm 2.02$ \\
Methionine & $23.13 \pm 1.54$ & $23.01 \pm 1.13$ & $22.16 \pm 1.24$ \\
Phenylalanine & $24.56 \pm 1.14$ & $24.49 \pm 1.23$ & $21.45 \pm 1.05$ \\
Tryptophan & $18.50 \pm 0.99$ & $18.48 \pm 1.12$ & $17.24 \pm 1.15$ \\
Histidine & $17.61 \pm 1.01$ & $17.46 \pm 1.14$ & $16.08 \pm 1.03$ \\
\hline \hline
\end{tabular}

Values are expressed as means \pm standard deviation

Table 4. Non-essential amino acids in cheddar, mozzarella and paneer whey (mg/g protein)

\begin{tabular}{llll}
\hline \hline $\begin{array}{l}\text { Non-essential } \\
\text { amino acids }\end{array}$ & $\begin{array}{l}\text { Cheddar } \\
\text { whey }\end{array}$ & $\begin{array}{l}\text { Mozzarella } \\
\text { whey }\end{array}$ & $\begin{array}{l}\text { Paneer } \\
\text { whey }\end{array}$ \\
\hline Glutamic acid & $144.51 \pm 3.41$ & $141.56 \pm 2.98$ & $137.67 \pm 3.22$ \\
Aspartic acid & $101.30 \pm 3.14$ & $99.34 \pm 3.17$ & $98.27 \pm 2.99$ \\
Proline & $62.08 \pm 3.01$ & $61.11 \pm 2.98$ & $60.34 \pm 3.11$ \\
Serine & $44.16 \pm 2.12$ & $43.12 \pm 1.97$ & $42.56 \pm 2.02$ \\
Alanine & $50.23 \pm 2.01$ & $50.11 \pm 2.04$ & $49.31 \pm 1.86$ \\
Arginine & $21.47 \pm 1.94$ & $21.14 \pm 2.01$ & $19.17 \pm 1.93$ \\
Tyrosine & $30.07 \pm 2.13$ & $29.12 \pm 1.99$ & $28.08 \pm 2.13$ \\
Glycine & $12.09 \pm 0.98$ & $11.32 \pm 1.04$ & $10.21 \pm 0.89$ \\
Cysteine & $15.05 \pm 0.89$ & $14.71 \pm 1.01$ & $13.87 \pm 0.88$ \\
\hline \hline
\end{tabular}

Values are expressed as means \pm standard deviation 
amino acids (Hulmi et al., 2010). In another study leucine was found in high concentration $(118 \mathrm{mg} / \mathrm{g})$ followed by lysine $(95 \mathrm{mg} / \mathrm{g})$ in whey protein concentrate whereas among the non-essential amino acids, maximum concentration was reported for glutamic acid $(154 \mathrm{mg} / \mathrm{g})$ followed by aspartic acid (107 mg/g) (Etzel, 2004).

\section{Conclusion}

Whey should be promoted as a valuable and economic source of high quality protein in daily diet. Novel processing technologies are adopted to introduce health supportive edibles from dairy industry by-products. Further studies should be carried out to manufacture value added products from whey through novel processing technologies for diverse applications. The results of this study will be beneficial for dairy, beverage and pharmaceutical industries for development of new products and processing methods.

\section{References}

AOAC, 2006. Official Methods of Analysis. $18^{\text {th }}$ edition, The Association of Official Analytical Chemists. Inc. Arlington, USA.

Djuri, M., Cari, M., Milanovi, S., Teki, M., Pani, M. 2004. Development of whey based beverages. Europian Food Research and Technology, 219: 321-328.

Etzel, M.R. 2004. Manufacture and use of dairy protein fractions. Journal of Nutrition, 134: 996S-1002S.

Gill, H.S., Rutherford, K.J., Cross, M.L.2000. Bovine milk. A unique source of immunomodulatory ingredients for functional foods. In: Functional Foods II-Claims and Evidence. J. Buttriss and M, Saltmarsh (eds.), pp. 82-90, Royal Society of Chemistry Press, Cambridge, England.

Goyal, N., Gandhi, D.N.2009. Comparative analysis of Indian paneer and cheese whey for electrolyte whey drink. World Journal of Dairy \& Food Sciences, 4: 70-72.

Hulmi, J.J., Lockwood, C.M., Stout, J.R.2010. Effect of protein/essential amino acids and resistance training on skeletal muscle hypertrophy: A case for whey protein. Nutrition \& Metabolism, 7: 1-11.

Ismail, A.E., Abdelgader, M.O., Ali, A.A. 2011. Microbial and chemical evaluation of whey based mango beverage. Advance Journal of Food Science and Technology, 3: 250-253.

Naik, Y.K., Khare, A., Choudhary, P.L., Goel, B.K., Shrivastava, A. 2009. Studies on physico-chemical and sensory characteristics of whey based watermelon beverage. Asian Journal of Research in Chemistry, 2: 57-59.

Olusola, O.J., Macdosnald, I.O., Mathew, M.O. 2012. Proximate composition of whey from South West Nigeria. Advances in Bioresearch, 3: 14-16.

Otte, J., Salaby, S., Zakora, M., Nielsen, M.S. 2007. Fractionation and identification of ACE-inhibitory peptides from $\alpha$-lactalbumin and $\beta$-casein produced by thermolysin-catalysed hydrolysis. International Dairy Journal, 17: 1460-1472.

Playne, M., Bennett, L.E., Smithers, G.W. 2003. Functional dairy foods and ingredients. Australian Journal of Dairy Technology, 58: 242-264.

Sakhale, B.K., Pawar, V.N., Ranveer, R.C. 2012. Studies on the development and storage of whey based RTS beverage from mango cv kesar. Journal of Food Processing and Technology, 3: 148-151.

Shukla, M., Tha, Y.K., Admasu, S. 2013. Development of probiotic beverage from whey and pineapple juice. Journal of Food Processing and Technology, 4: 206-209.

Singh, D., Singh, R., Bhatt, F. 2014. Development, quality evaluation and shelf life studies of whey guava beverage. International Journal of Current Engineering and Technology, 4: 2171-2175.

Singh, W., Kapoor, C.M., Srivastava, D.N.1999. Standardisation of technology for the manufacture of guava- whey beverage. Indian Journal of Dairy Science, 52: 268-270.

Smithers, G.W. 2008. Whey and whey proteins-From gutter-to-gold. International Dairy Journal, 18: 695-704.

Steel, R.G., Torrie, J.H., Dickey, D.A.1997. Principles and Procedures of Statistics-A Biometrical Approach. $3^{\text {rd }}$ edition, McGraw Hill Book Co. Inc., New York, USA.

Walsh, M.K., Brown, R.J. 2000. Use of amino acid analysis for estimating the individual concentrations of proteins in mixtures. Journal of Chromatography A, 891: 355-360.

Wang, J., Zang, Q.H., Wang, Z.H., Li, H.M. 2009. Determination of major bovine milk proteins by reversed phase high performance liquid chromatography. Chinese Journal of Analytical Chemistry, 37: 1667-1670.

Yousef, A.E., Calstrom, C. 2003. Food Microbiology A Laboratory Manual. $1^{\text {st }}$ edition, Wiley-Interscience. A John Wiley and Sons Inc., New Jersey, USA.

Zimecki, M., Kruzel, M.L. 2007. Milk-derived proteins and peptides of potential therapeutic and nutritive value. Journal of Experimental Therapeutics and Oncology, 6: 89-106. 